SCIENTIFIC COMMUNICATION

\title{
Occurrence of white-winged vampire bat, Diaemus youngi (Mammalia, Chiroptera), in the Cerrado of Distrito Federal, Brazil
}

\author{
Ludmilla M. de S. Aguiar; Willian R. de Camargo \& Alexandre de S. Portella
}

Laboratório de Ecologia de Vertebrados, Embrapa Cerrados, CPAC. Rodovia BR 020, km 18, Caixa Postal 08223, 73301-970 Planaltina, Distrito Federal, Brasil. E-mail: ludmilla@cpac.embrapa.br

\begin{abstract}
Authors cite Diaemus youngi (Jentik, 1893) as occurring in all the Brazilian territory. In spite of that, there are no reports of capture sites for $D$. youngi in the literature for Distrito Federal or Cerrado of Central Brazil. Here we report the first precise record of this species for Central Brazil, rural area of Distrito Federal, and provide information on its biology, conservation and distribution in Brazil, according to our data and information from the literature.

KEY WORDS. Caves; conservation; ectoparasites; karstic area; Streblidae.
\end{abstract}

RESUMO. Ocorrência de Diaemus youngi (Mammalia, Chiroptera) no Cerrado do Distrito Federal. A espécie Diaemus youngi (Jentik, 1893) é considerada por alguns autores como ocorrendo para todo o Brasil incluindo o bioma Cerrado e área rural do Distrito Federal. No entanto não há na literatura nenhum registro do local de coleta dessa espécie para essas regiões. Reportamos aqui o primeiro registro no Cerrado do Brasil Central, área rural do Distrito Federal, e alguns dados sobre a biologia, conservação e distribuição geográfica da espécie no Brasil, de acordo com dados desse trabalho e da literatura.

PALAVRAS-CHAVE. Área cárstica; cavernas; conservação; ectoparasitas; Streblidae.

Hematophagous bats, also called vampire bats, are fascinating mammals due to their social structure and their complex anatomical and physiological characters. Their subfamily, Desmodontinae, is composed of the only three bat species that feed on blood from either mammals and birds.

Diaemus youngi resembles Desmodus rotundus (E. Geoffroy 1810) and Diphylla ecaudata Spix, 1823, but can be easily distinguished from these other vampires because it lacks a calcar and has no evident tail. The thumb of $D$. youngi has a single pad, while $D$. rotundus has two. In $D$. youngi, both sexes posses cupshaped oral scent glands located bilaterally inside the mouth. These glands are seen only when the bat is disturbed; it directs the glands forward and they emit offensive odor (GREENHALL \& SchutT 1996). The edges of its ears and wings are white, as well as the membrane between the second and third fingers. Pelage color goes from light to dark brown. It has preference for birds' blood but feeds on mammals' blood too (UIEDA 1993).

The white winged vampire bat occurs from northeastern Mexico through Central America. In South America, its range extends from the Amazon basin to northern Argentina. Nevertheless, D. youngi is locally rare or uncommon throughout most of its geographic range (Greenhall \& SchutT 1996).

Authors cite this species as occurring in all the Brazilian territory (Koopmam 1982, Margarido \& Braga 2004) including the Cerrado (Marinho-Filho 1996, Marinho-Filho et al. 2003) and rural area of the Distrito Federal (BREDT \& Uieda 1996). In spite of that, there are no reports of capture sites for D. youngi in the literature for Distrito Federal or Central Brazil. Here we report the first precise record of this species for the Distrito Federal, and provide updated information on its biology and distribution in Brazil, according to our data and information from the literature.

Mist nets were opened at roost entrance, in a cave known as Sal-Fenda (15 $\left.30^{\prime} \mathrm{S}-48^{\circ} 10^{\prime} \mathrm{W}\right)$. The cavity is in a large granite block within a farm called Sarah, located in the municipality of Brazlândia, at $840 \mathrm{~m}$ of altitude. It is surrounded by pasture and degraded area of semi-deciduous forest. The municipality is within the Cafuringa Area of Environmental Protection (APA)' domain (Fig. 1). This area has 46,000 ha and harbours large areas of dry forest that extends to Tocantins basin and is the only one in the Distrito Federal on karstic terrain. Measurements were made with calipers (accuracy 0.05 $\mathrm{mm}$ ) and generally followed the protocol described by TADDEI \& Uieda (2001). One voucher specimen is preserved in alcohol $70 \%$ and was incorporated to the chiroptera collection of Embrapa Cerrados. Ectoparasites were captured with clamp of watchmaker and stored in alcohol 70\% (Whitaker 1988). Dis- 


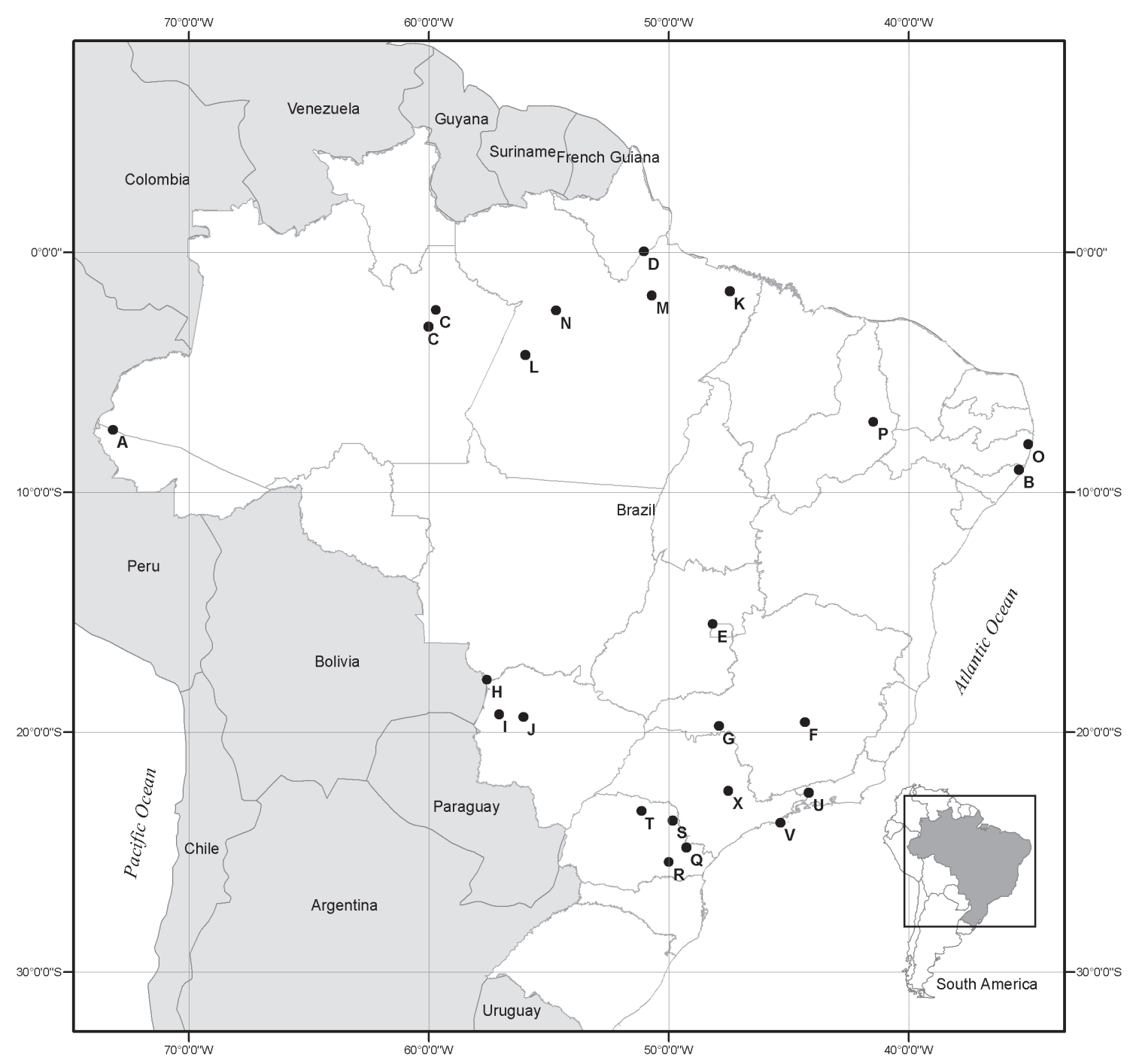

Figure 1. Map showing localities recorded for Diaemus youngi in the Brazilian territory, including the site of this study, in the municipality of Brazlândia, within the Cafuringa Area of Environmental Protection (APA) domain, Distrito Federal, Brazil. 1) Acre (A) Cruzeiro do Sul (Nocueira et al. 1999), 2) Alagoas (B) Porto Calvo (R.A. Silva pers. comm.), 3) Amazonas (C) Manaus (Mok \& LaCey 1980, Bernard 2001), 4) Amapá (D) Macapá (Peracchi et al. 1984), 5) Distrito Federal (E) Brazlândia (this paper), 6) Mato Grosso do Sul (F) Corumbá (SCHAller 1983), (G) Aquidauana (Leite et al. 1998); 7) Minas Gerais (H) Esmeraldas (Uieda 1993), (I) Uberaba (Stutz et al. 2004); 8) Pará (J) Belém, (K) lataituba (Reis \& Schubart 1979), (L) Melgaço (Marques-Aguiar et al. 2003), (M) Santarém (Piccinini 1974); 9) Paraná (N) Cerro Azul (Gracioll \& Carvalho 2001), (O) Palmeira (Thomas 1899), (P) Siqueira Campos (Margarido \& BraGa 2004), (Q) Londrina (Reis et al. 2003); 10) Pernambuco (R) São Lourenço da Mata (Mares et al. 1981); 11) Piauí (S) Picos (PINto \& Bento 1986); 12) Rio de Janeiro (T) Barra Mansa (Peracchi \& Albuquerque 1971); 13) São Paulo (U) Itabera, (V) Santa Gertrudes (Uieda 1993).

tribution map of D. youngi was done using data collected in current literature and was plotted using Arc GIS version 9.

Eight adult individuals were captured during the rainy season of 2004 (one male in October at $20 \mathrm{~h} 30 \mathrm{~m}$, two males in November at 20:00 and 23:00 h, one male in December at 20:00 $\mathrm{h}$, three males in January at 19:30 $\mathrm{h}$ and one female in February at 20:00 h). Bats were caught when leaving their roost.
Diaemus youngi was sharing the roost with Peropteryx macrotis (Wagner, 1843), Platyrrhinus lineatus (E. Geoffroy, 1810), Sturnira lilium (E. Geoffroy, 1810), Anoura sp., Artibeus sp., Carollia perspicillata (Linnaeus, 1758), D. rotundus (E. Geoffroy, 1810), D. ecaudata Spix, 1823, Lonchophylla dekeyseri Taddei, Vizotto \& Sazima, 1983, Phyllostomus hastatus (Pallas, 1767) and Chrotopterus auritus (Peters, 1856). 
Four adult males weight measures were $39 \mathrm{~g}, 35 \mathrm{~g}, 35 \mathrm{~g}$, $35 \mathrm{~g}$ and one adult female was $37 \mathrm{~g}$. Forearm lengths of two males were 52 and $53 \mathrm{~mm}$. All males but one had scrotal testis. The only captured female had no signs of pregnancy or lactation.

A total of 135 streblid flies were collected from eigth $D$. youngi specimens. Individual infestation varied from five to 39 ectoparasites collected on bat's body. Fly species were Strebla diaemi Wenzel, 1966 and Trichobius diaemi Wenzel, 1976. There were also six mites belonging to two unidentified species.

In literature we found $D$. youngi registered in thirteen of the 26 Brazilian states, including this paper (Fig. 1).

Diaemus youngi is a cave and tree dwelling species, roosting in colonies of up to 30 individuals (GreENHALl \& SCHutT 1996) and exhibits dominance-hierarchy behavior, and behavioral patterns unreported in other species of bats (SchutT et al. 1999). In this study, we only captured eight bats, which were sharing the cave with $D$. rotundus and other species. Differences in feeding behavior related to selection of prey, arboreal versus terrestrial prey, reduce competition in places where $D$. rotundus and D. youngi coexist (SCHUTT et al. 1999).

Diaemus youngi is a bat of medium size and its weight varies between 30 and $38 \mathrm{~g}$. Body measures $80-85 \mathrm{~mm}$, and forearm 50-55 mm (Greenhall \& SChutT 1996). The measures found in this paper are in accordance with the ones given in literature.

Reproduction of this species is not very well known (GREENHALL \& SCHUTT 1996). Male bats were reproductive at the rainy season in our study area. As we caught Diaemus only at the rainy season (although netting was done during dry and rainny seasons), we suspect that the species leaves the cave during the dry period and returns in the rainy season for its reproduction.

Ectoparasites found on Diaemus youngi include two families of mites and bat flies of Streblidae (see GreEnHall \& Schutt 1996). The species T. diaemi and $S$. diaemi found in this study are considered species specific and are the first occurrences for the Cerrado biome. According to FriTz (1983), bat ectoparasites knowledge offers important information to understand biological, systematic, and phylogenetic aspects of the hosts, and also to clarify epidemiological aspects of the transmission of some diseases among bats. This new record may provide more information on ecological aspects of the relationships between batflies and their hosts belonging to the family Phyllostomidae in Central Brazil.

Species abundance and geographic distribution relation is the main subject in current ecological studies (see GASTON 1990, Gaston \& LAWTON 1990). This relationship has implications in the understanding of community structure, description of biodiversity patterns, as well as for proposing and testing hypotheses regarding the processes underlying these patterns (GASTON \& BLACKBURN 1996). Data on D. youngi in Brazil reveal local rarity, despite its wide distribution. The status of D. youngi populations, its distribution, as well as its biology and ecology are poorly known. Due to its similarity with $D$. rotundus, the species is doubtlessly, negatively affected by vampire control because it can be confused with $D$. rotundus. Although the rabies virus was already isolated in individuals of D. youngi in Brazil, all reports of outbreaks of human aggression and human rabies caused by vampire bats are related to activities of Desmodus rotundus (GONÇALVEs et al. 2002). There are chicken farms in the neighborhood of the studied area, but no claim of vampire bat attacks on them. The opposite occurs with cattle. The farmers complain of vampire attacks and there are bovine rabies occurrences in the region (A. Bredt pers. comm.). Diphylla ecaudata and Diaemus youngi have low densities, feed preferentially on blood of birds, and more studies are necessary to justify their presence in vampire population control programs (see Aguiar \& TADDEI 1995).

It is widely known that caves are used as roosts by many bat species in Brazil (Trajano 1995) and this paper corroborates this. All bat population in karstic regions, even not threatened, should be object of a preservationist policy because they supply main resources (guano) for the maintenance of cave communities (Aguiar \& TADdei 1995). The main threats to D. youngi are caves destruction, destruction of habitats and deforestation. Suggested activities for protecting $D$. youngi are education of rural populations; more research to evaluate its distribution, biology and ecology; management of $D$. rotundus populations in rural areas with cattle; and also the protection and recovery of habitats. Diaemus youngi is considered threatened in the states of Paraná (Margarido \& Braga 2004) and Rio de Janeiro (Bergallo et al. 2000), and it should be always considered in the analysis processes of species threatened lists in states that have significant livestock.

\section{ACKNOWLEDGMENTS}

To MMA/PROBIO/CNPq and IBAMA, Gustavo Graciolli, Angelika Bredt, Marco A. Mello, and two anonymous refereees. This paper is one of the results of the Action Plan for Lonchophylla dekeyseri project, supported by MMA/PROBIO/FNMA. Capture license 118/2003 - CGFAU/LIC.

\section{REFERENCES}

Aguiar, L.M.S. \& V.A. TAddei. 1995. Lista da Fauna Ameaçada de Extinção no Estado de Minas Gerais. Chiroptera Neotropical, Belo Horizonte, 1 (2): 31.

Bergallo, H.G.; C.F.D. Rocha; M.A.S. Alves \& M.V. Sluys. 2000. A fauna ameaçada de extinção do Estado do Rio de Janeiro. Rio de Janeiro, Editora Universidade do Estado do Rio de Janeiro, 166p.

BernARD, E. 2001. Vertical Stratification of bat communities in primary forests of Central Amazon, Brazil. Journal of Tropical Ecology, Cambridge, 17: 115-126.

BREdT, A. \& W. Uieda. 1996. Bats from urban and rural environments of the Distrito Federal, Mid-western Brazil. Chiroptera Neotropical, Belo Horizonte, 2 (2): 54-57.

Fritz, G.N. 1983. Biology and ecology of bat flies (Diptera: Streblidae) on bats in the genus Carollia. Journal of Medical Entomology, Lanham, 20:1-10.

Gaston, K.J. 1990. Patterns in the geographical ranges of species.

Revista Brasileira de Zoologia 23 (3): 893-896, setembro 2006 
Biological Reviews, Cambridge, 65: 105-129.

Gaston, K.J. \& T.M. BlackBurn. 1996. Global scale macroecology: interactions between population size, geographic range size and body size in the Anseriformes. Journal of Animal Ecology, London, 65: 701-714.

GASTON, K.J. \& J.H. LAwTON. 1990. Effects of scale and habitat on the relationship between regional distribution and local abundance. Oikos, Lund, 58: 329-335.

Gonçalves, M.A.S.; R.J. SA-Neto \& T.K. Brazil. 2002. Outbreak of aggressions and transmission of rabies in human beings by vampire bats in northeastern Brazil. Revista da Sociedade Brasileira de Medicina Tropical, Uberaba, 35 (5): 453-460.

Graciolli, G. \& C.J.B. Carvalho 2001. Moscas ectoparasitas (Diptera, Hippoboscoidea) de morcegos (Mammalia, Chiroptera) do Estado do Paraná. II. Streblidae. Chave pictórica para gêneros e espécies. Revista Brasileira de Zoologia, Curitiba, 18 (3): 907-960.

Greenhall, A.M. \& W.A. Schutt JR. 1996. Diaemus youngi. Mammalian Species, Washington, 533: 1-7.

Kоормам, K.F. 1982. Biogeography of the Bats of South America, p. 273-302. In: M.A. MARes \& H.H. Genoways (Eds). Mammalian biology in South America. Pittsburgh, The Pymatuning Symposia in Ecology, Special Publication Series, Pymatuning Laboratory of Ecology, University of Pittsburgh, vol. 6, 539p.

Leite, A.P.; M. Meneghelli \& V.A. TAddei. 1998. Morcegos (Chiroptera: Mammalia) dos pantanais de Aquidauana e da Nhecolândia, Mato Grosso do Sul. I. Diversidade de espécies. Ensaios e Ciência, Campo Grande, 2 (2): 167-174.

Mares, M.A.; M.R. Willig; K.E. Streilein \& T.E. Lacher. 1981. The Mammals of northeastern Brazil: a preliminary assessment. Annals of Carnegie Museum, Pittsburgh, 50 (4): 81-137.

Margarido, T.C.C. \& F.C. Braga. 2004. Mamíferos, p. 27-142. In: S.B. Mikich \& R.S. BÉRnILS (Eds). Livro vermelho da fauna ameaçada no Estado do Paraná. Curitiba. Instituto Ambiental do Paraná, 763p.

Marinho-Filho, J. 1996. The Brazilian Cerrado bat fauna and its Conservation. Chiroptera Neotropical, Belo Horizonte, 2 (1): 37-39.

Marinho-Filho, J.; F.H.G. Rodrigues \& K.M. Juarez. 2003. The Cerrado mammals: diversity, ecology and natural history, p. 266-284. In: P.S. Oliveira \& R.J. Marquis (Eds). The Cerrados of Brazil: ecology and natural history of a Neotropical Savanna. New York, Columbia University Press, 367p.

Marques-Aguiar, S.A.; M.V. del Aguila; G.F.S. Aguiar; N. Saldanha; J.S. Silva-Junior \& M.M.B. Rocha. 2003. Caracterização e perspectivas de estudo dos quirópteros da Estação Científica Ferreira Penna - Municipio de Melgaço, PA. Idéias e Debates, Belém, 6: 1-3.

MoK, W.Y. \& L.A. LACEY.1980. Algumas considerações ecológicas sobre morcegos vampiros na epidemiologia da raiva humana na Bacia Amazônica. Acta Amazônica, Manaus, 10 (2): 335-342.

Nogueira, M.R.; A. Pol \& A.L. Peracchi. 1999. New records of bats from Brazil with a list of additional specie for the chiropteran fauna of the state of Acre, Western Amazon basin. Mammalia, Paris, 63 (3): 363-368.

Peracchi, A.L.; S.D.L. Raimundo \& A.M. Tannure. 1984. Quirópteros do Território Federal do Amapá, Brasil (Mammalia, Chiroptera). Arquivos da Universidade Federal Rural do Rio de Janeiro, Seropédica, 7 (2): 89-100.

Peracchi, A.L. \& S.T. Albuquerque. 1971. Lista provisória dos quirópteros dos estados do Rio de Janeiro e Guanabara, Brasil (Mammalia: Chiroptera). Revista Brasileira de Biologia, Rio de Janeiro, 31 (3): 405-413.

PICCININI, R.S. 1974. Lista provisória dos quirópteros da coleção do Museu Parense Emílio Goeldi (Chiroptera). Boletim do Museu Paraense Emílio Goeldi, Belém, 77: 1-33.

Pinto, A.S. \& D.N.C. Bento. 1986. Trypanossoma cruzi like bloodstream trypomastigotes in bats from the state of Piauí, northeastern Brazil. Revista da Sociedade Brasileira de Medicina Tropical, Uberaba, 19 (1): 31-34.

Reis, N.R. \& H.O.R. Schubart.1979. Notas preliminares sobre os morcegos do Parque Nacional da Amazônia (médio Tapajós). Acta Amazonica, Manaus, 9 (3): 507-515.

Reis, N.R.; M.L. Barbieri; I.P. de Lima \& A.L. Peracchi. 2003. What is better for maintaining the richness of bat (Mammalia, Chiroptera) species: A large forest fragment or many small fragments? Revista Brasileira de Zoologia, Curitiba, 20 (2): 225-230.

Schaller, G.B. 1983. Mammals and their biomass on a Brazilian Ranch. Arquivos de Zoologia, São Paulo, 31(1):1-36.

Schutt, W.A. Jr, F. Muradali; N. Mondol; K. Joseph \& K BrockMANN.1999. Behavior and maintenance of captive whitewinged vampire bats, Diaemus youngi. Journal of Mammalogy, Provo, 80 (1): 71-81.

Stutz, W.H.; M.C. Albuquerque; W. Uieda; E.M. Macedo; C.B. FranCA. 2004. Updated list of Uberlândia bats (Minas Gerais State, Southeastern Brazil). Chiroptera Neotropical, Brasília, 10 (2): 188-190.

TAdDei, V.A. \& W. UiedA. 2001. Distribution and morphometrics of Natalus stramineus from South America (Chiroptera, Natalidae). Iheringia, Série Zoologia, Porto Alegre, 91: 123-132.

Thomas, O. 1899. List of the mammals obtained by Dr. Franco Grillo in the Province of Paraná, Brazil. Annali del Museo Civico di Storia Naturale, Genova, 2 (20): 546-549.

Trajano, E. 1995. Protecting caves for bats or bats for the caves? Chiroptera Neotropical, Belo Horizonte, 1 (2): 19-22.

Uieda, W. 1993. Comportamento alimentar do morcego hematófago Diaemus youngi, em aves domésticas. Revista Brasileira de Biologia, Rio de Janeiro, 53 (4): 529-538.

Whitaker JR, J.O. 1988. Collecting and preserving ecotoparasites for ecological studies, p. 459-474. In: T.H. Kunz (Ed.). Ecological and behavioral methods for the study of bats. Washington, Smithsonian Institution Press, 533p.

Received in 032.I.2006; accepted in 26.VIII.2006. 